Published in final edited form as:

Ann N Y Acad Sci. 2006 December ; 1091: 336-345.

\title{
Effects of $\mathrm{AT}_{1}$ Receptor-Mediated Endocytosis of Extracellular Ang II on Activation of Nuclear Factor-kB in Proximal Tubule Cells
}

\author{
JIA L. ZHUO, OSCAR A. CARRETERO, and XIAO C. LI \\ Laboratory of Receptors and Signal Transduction, Division of Hypertension and Vascular Research, \\ Henry Ford Hospital, Detroit, Michigan 48202, USA
}

\section{Abstract}

Angiotensin II (Ang II) exerts powerful proinflammatory and growth effects on the development of Ang II-induced hypertensive glomerulosclerosis and tubulo-interstitial fibrosis. The proinflammatory and growth actions of Ang II are primarily mediated by activation of cell surface type 1 receptors $\left(\mathrm{AT}_{1}\right)$ and the transcription factor nuclear factor- $\mathrm{\kappa B}(\mathrm{NF}-\kappa \mathrm{B})$. However, binding of cell surface receptors by extra-cellular Ang II also induces receptor-mediated endocytosis of the agonist-receptor complex in renal cells. The purpose of the present study was to determine whether $\mathrm{AT}_{1}$ receptor-mediated endocytosis of extracellular Ang II is required for Ang II-induced NF- $\mathrm{kB}$ activation and subsequent proliferation of rabbit renal proximal tubule cells. Expression of $\mathrm{AT}_{1}$ (primarily $\mathrm{AT}_{1 \mathrm{a}}$ or human $\mathrm{AT}_{1}$ ) receptors in these cells was confirmed by Western blot, showing that transfection of a human $\mathrm{AT}_{1}$ receptor-specific 20-25 nucleotide siRNA knocked down more than $70 \%$ of $\mathrm{AT}_{1}$ receptor protein $(P<0.01)$. Stimulation of proximal tubule cells by Ang II $(1 \mathrm{nM})$ induced fourfold increases in NF- $\mathrm{kB}$ activity $(P<0.01)$. The Ang II-increased NF- $\mathrm{kB}$ activity was significantly attenuated by coadministration of losartan $(10 \mu \mathrm{M})$, an $\mathrm{AT}_{1}$ receptor-selective blocker, or colchicine $(1 \mu \mathrm{M})$, a selective cytoskeleton microtubule inhibitor known to block receptormediated endocytosis $(P<0.01)$. Furthermore, Ang II significantly increased ${ }^{3} \mathrm{H}$-thymidine incorporation $(>55 \%, P<0.01)$, an index of cell proliferation and DNA synthesis, and the effect was also attenuated by coadministration of losartan and colchicine $(P<0.01)$. Our results therefore suggest that $\mathrm{AT}_{1}$ receptor-mediated endocytosis of extracellular Ang II may be required for Ang IIinduced NF- $\mathrm{KB}$ activation and subsequent cell proliferation in renal proximal tubule cells.

\section{Keywords}

angiotensin II; cell proliferation; chemokine; cytokines; kidney

\section{INTRODUCTION}

Angiotensin II (Ang II) has been recognized for several decades as a vasoactive peptide that plays an important role in physiological regulation of renal sodium and fluid reabsorption and blood pressure homeostasis. However, an increasing effort has recently been directed to studying the potential role of Ang II as a powerful proinflammatory cytokine and growth factor in the pathogenesis of many progressive renal diseases, including Ang II-induced hypertensive glomerulosclerosis and tubulo-interstitial fibrosis. ${ }^{1-3}$ Indeed, there is accumulating evidence that Ang II can affect the transcription of genes related to cell growth and proliferation. ${ }^{4}$ Ang II has been shown to induce expression of protooncogenes and genes for growth factors, extracellular matrix and hypertrophic markers. ${ }^{4}$ Although not classified as gene transcriptionmodulating drugs, ACE inhibitors, which block Ang II formation, and $\mathrm{AT}_{1}$ receptor

Address for correspondence: Jia L. Zhuo M.D., Ph.D., Division of Hypertension and Vascular Research, Henry Ford Hospital, 2799 West Grand Boulevard, Detroit, MI 48202, USA. Voice: 1-313-916-0018; fax: 1-313-916-1479. e-mail: jzhuo1@ @ hfhs.org. 
antagonists, which block Ang II type 1 receptors, have been shown to prevent gene expression induced by Ang II, thereby supporting an important role of Ang II in promoting inflammation and cell growth. The growth-promoting and proliferative effects of Ang II may be partly mediated by activating cell surface $\mathrm{AT}_{1}$ receptors or by intracellular Ang II acting on intracellular Ang II receptors. 5,6 It is interesting to note that intracellular Ang II may stimulate cytoplasmic receptors to activate a variety of intracellular kinases, leading to phosphorylation of many cytoplasmic and nuclear proteins, such as extracellular signal-regulated protein kinase (s) (ERKs), ${ }^{7}$ JAK-STAT signaling, ${ }^{8}$ and calcineurin phosphatase. ${ }^{9}$

Although Ang II is known to induce target organ damage in cardiovascular and renal tissues by activating a number of proinflammatory cytokines and growth factors, the precise mechanisms are far from fully understood. ${ }^{1-3}$ Numerous studies suggest that nuclear factor$\kappa \mathrm{B}(\mathrm{NF}-\kappa \mathrm{B})$ may be the key factor in mediating Ang II-induced inflammatory responses and tissue injury. For example, infusion of Ang II in rats increased renal and vascular smooth muscle cell NF- $\kappa \mathrm{B}$ binding activity, and activation of NF- $\kappa \mathrm{B}$ was associated with increases in inflammatory cell infiltration and tubulo-interstitial inflammation. ${ }^{10}$ In rats harboring both human renin and angiotensinogen genes and thereby producing high circulating and tissue Ang

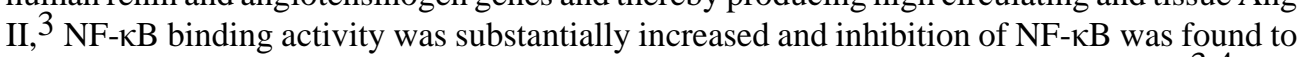
ameliorate Ang II-induced inflammatory target organ damage in the heart and kidney. ${ }^{3,4} \mathrm{NF}$ $\kappa \mathrm{B}$ is an important transcription factor in inflammatory diseases, and activation of NF- $\kappa \mathrm{B}$ by Ang II in turn stimulates transcription of many cytokines and chemokines, including angiotensinogen, monocyte chemoattractant peptide-1 (MCP-1), transforming growth factor (TGF) $\beta$, and RANTES (regulated on activation normal T cell expressed and secreted). ${ }^{11}$ When not activated, $\mathrm{NF}-\kappa \mathrm{B}$ exists in an inactive form in the cytoplasm, binding to inhibitory I $\mathrm{B}$ proteins. Stimulation of cells results in phosphorylation and degradation of $\mathrm{I} \kappa \mathrm{B}$ proteins, which releases $\mathrm{NF \kappa B}$ dimers. These dimers are translocated to the nucleus, where they activate appropriate target genes. ${ }^{12,13}$ Although it is commonly presumed from in vivo studies that Ang II activates NF- $\mathrm{BB}$ through cell surface receptor-mediated signaling to induce tubulointerstitial inflammation, it is not known whether intracellular Ang II plays any role in this response. In addition to activating cell surface receptors, extracellular Ang II is also internalized after binding to cell membrane $\mathrm{AT}_{1}$ receptors. ${ }^{14}$ In the present study, we used rabbit proximal tubule cells as a model to test the hypothesis that $\mathrm{AT}_{1}$ receptor-mediated Ang II endocytosis is required for Ang II-stimulated NF- $\mathrm{B}$ activation and promotion of its translocation into the nucleus.

\section{MATERIALS AND METHODS}

\section{Proximal Tubule Cell Culture}

Cultured proximal tubule cells were obtained from American Type Culture Collection (vEPT, ATCC) and subcultured as described previously. ${ }^{15,16}$ These cells were derived from the S1 segment of rabbit kidney proximal tubules and have been shown to express major components of the renin-angiotensin system, including angiotensinogen, renin, angiotensin-converting enzyme, and Ang II receptors, ${ }^{15}$ and response to Ang II. ${ }^{16}$ In the present study, unless specified otherwise, proximal tubule cells were subcultured in 6-well plates in complete DMEM/F-12 growth medium supplemented with $50 \mathrm{nM}$ hydrocortisone, $5 \%$ heat-inactivated fetal bovine serum, $100 \mathrm{U} / \mathrm{mL}$ penicillin and $100 \mu \mathrm{g} / \mathrm{mL}$ streptomycin. Cells were maintained at $37^{\circ} \mathrm{C}$ and $95 \% \mathrm{O}_{2} / 5 \% \mathrm{CO}_{2}$ and fed every 2-3 days. Serum was removed from the medium for $24 \mathrm{~h}$ before the experiments began. $15-17$

\section{Western Blot of $\mathrm{AT}_{1 \mathrm{~A}}$ Receptor Protein Expression}

To confirm that proximal tubule cells express $\mathrm{AT}_{1}$ receptors, sub-confluent, serum-starved cells were either treated with medium alone or transfected with an $\mathrm{AT}_{1 \mathrm{~A}}$ receptor-specific 20 
25 nucleotide siRNA ( $\mathrm{AT}_{1} \mathrm{R}$ siRNA) (Santa Cruz Biochemicals, Santa Cruz, CA, USA) for 48 to $72 \mathrm{~h}$ as described previously. ${ }^{17,18}$ After treatment, the cells were washed twice with icecold phosphate-buffered saline and lysed with a modified RIPA buffer ( $50 \mathrm{mM}$ Tris-HCl, 50 $\mathrm{mM}, 1 \%$ NP-40, $0.25 \%$ Na-deoxycholate, $150 \mathrm{mM} \mathrm{NaCl}, 1 \mathrm{mM}$ EDTA, $1 \mathrm{mM}$ PMSF, $1 \mu \mathrm{g} /$ $\mathrm{mL}$ each of aprotinin, leupeptin, and pepstatin, $1 \mathrm{mM} \mathrm{Na} \mathrm{VO}_{3}$, and $1 \mathrm{mM} \mathrm{NaF}, \mathrm{pH}$ 7.4). Proteins were extracted and samples $(10 \mu \mathrm{g}$ each) were electrophoretically separated on 8 $16 \%$ Tris-glycine gels as described previously. ${ }^{16,17}$ After SDS separation, proteins were transferred to Millipore Immobilon-P membranes, and the membranes were blotted overnight at $4{ }^{\circ} \mathrm{C}$ with $5 \%$ nonfat dry milk and incubated for $3 \mathrm{~h}$ at room temperature with a primary rabbit anti- $\mathrm{AT}_{1}$ receptor polyclonal antibody raised against the $\mathrm{N}$-terminal extracellular domain of $\mathrm{AT}_{1}$ receptors (1:200; SC-1173, Santa Cruz). ${ }^{16,17}$ To ensure equal protein loading, the same membranes were treated with a stripping buffer (Pierce Biotechnology) for $20 \mathrm{~min}$, blotted with 5\% nonfat dry milk, and reprobed with a mouse anti- $\beta$-actin monoclonal antibody at 1:2000 (Sigma-Aldrich, St. Louis, MO, USA). Western blot signals were detected using enhanced chemiluminescence (Amersham Piscataway, NJ, USA) and analyzed using a microcomputer imaging device with a digital camera (MCID, Imaging Research, St. Catherines, Ontario, Canada).

\section{Measurement of Activated Nuclear Transcription Factor NF-KB in Nuclear Extracts}

To determine whether $\mathrm{AT}_{1}$ receptor-mediated endocytosis of extracellular Ang II is required for activation of Ang II on NF- $\mathrm{KB}$ in proximal tubule cells, we studied the effects of the endocytotic machinery inhibitors or the $\mathrm{AT}_{1}$ receptor blocker losartan on NF- $\mathrm{KB}$ activity in cell nuclear extracts. Subconfluent cells plated in 6-well plates were treated for $60 \mathrm{~min}$ at $37^{\circ}$ $\mathrm{C}$ according to the following protocols: (i) medium alone; (ii) lipopolysaccharide (LPS) only $(5 \mu \mathrm{g} / \mathrm{mL})$, a well-known NF-KB activator that served as a positive control ${ }^{13}$; (iii) Ang II only $(1 \mathrm{nM})$; (iv) Ang II + colchicine $(1 \mu \mathrm{M})$, which inhibits endocytosis in a non-Ang II-selective fashion by disrupting cytoskeleton microtubules; ${ }^{17,19}$ (v) Ang II + PAO $(10 \mu \mathrm{M})$, which

blocks cell surface $\mathrm{AT}_{1}$ receptor internalization by inhibiting tyrosine phosphatase; ${ }^{17,20}$ (vi) Ang II + losartan $(10 \mu \mathrm{M})$, which blocks cell surface $\mathrm{AT}_{1}$ receptor-mediated Ang II internalization; 9,14 and (vii) Ang II + PD $123319(10 \mu \mathrm{M})$, which inhibits $\mathrm{AT}_{2}$ receptors and has been reported to mediate Ang II-induced NF- $\mathrm{KB}$ activation in VSMCs and COS-7 cells. 21,22 After treatment, nuclear extracts were prepared using a commercial kit (Active Motif, Carlsbad, CA, USA). In brief: cells were washed with a PBS/phosphatase inhibitor solution, scraped into tubes, and lysed in a lysis buffer containing a DTT/protease inhibitor cocktail. Nuclear fractions were collected for measurements of activated NF- $\kappa B$ using commercial Trans NF- $\kappa$ B ELISA for p65 and p50 (Active Motif).

\section{Measurement of Proximal Tubule Cell Proliferation}

To determine whether Ang II stimulates proximal tubule cell proliferation, we measured $\left[{ }^{3} \mathrm{H}\right]$ thymidine incorporation, an index of DNA synthesis and cell proliferation. ${ }^{23-25}$ Cells were split into 6-well plates and incubated in DMEM/F12 growth medium for $2-3$ days (10 $/$ well). Subconfluent cells were treated with serum-free medium (control; $n=6$ wells), Ang II ( $1 \mathrm{nM}$, $n=6$ wells), Ang II plus the $\mathrm{AT}_{1}$ receptor blocker losartan (10 $\mu \mathrm{M}, n=6$ wells), Ang II plus the $\mathrm{AT}_{2}$ receptor blocker PD123319 (10 $\mu \mathrm{M}, n=6$ wells), or Ang II plus the endocytotic inhibitor colchicine $(1 \mu \mathrm{M})$, and pulsed with $1 \mu \mathrm{Ci} / \mathrm{mL}\left[{ }^{3} \mathrm{H}\right]$-thymidine for 24 h. ${ }^{17,19} \mathrm{After}$ treatment, the medium was removed and cells were washed with ice-cold phosphate-buffered saline (PBS) and lysed with $200 \mathrm{mM} \mathrm{NaOH}$ and $0.25 \%$ SDS. The contents were transferred to tubes, vacuum-filtered, and washed four times with $5 \mathrm{~mL}$ ethanol/TCA (70\%/5\%) using a Brandel cell harvester. Incorporated $\left[{ }^{3} \mathrm{H}\right]$ thymidine was counted in vials containing $4 \mathrm{~mL}$ scintillation cocktail as described previously. ${ }^{17,19}$ 


\section{STATISTICAL ANALYSIS}

Results are expressed as mean \pm SEM. Unless otherwise specified, six samples from two separate experiments were collected for each treatment and assayed in duplicate, including Western blot. Differences between two treatments were compared by Student's unpaired $t$-test, while differences between more than two treatments were analyzed by one-way analysis of variance, followed by a Newman-Keuls test for multiple comparisons. A $P<0.05$ was considered significant.

\section{RESULTS AND DISCUSSION}

Chronic administration of Ang II in rats is characterized by development of Ang II-dependent hypertension, accompanied by accumulation of Ang II in renal cortical endosomes ${ }^{5}$ and tubulointerstitial inflammatory injury in the kidney. ${ }^{1} \mathrm{NF}-\mathrm{\kappa B}$ has been suggested to play an important role in recruiting inflammatory cells to the tubulo-interstitium in Ang II-induced hypertensive renal injury, $3,4,10$ but it is not known whether Ang II induces activation of NF- $\kappa$ B and stimulates proliferation of cultured proximal tubule cells. In the present study, we used rabbit proximal tubule cells as an in vitro model to study the potential role of $\mathrm{AT}_{1}$ receptor-mediated Ang II endocytosis in activation of NF- $\kappa \mathrm{B}$ and the cellular mechanisms involved. Figure 1 shows Western blots of $\mathrm{AT}_{1}$ receptor protein expression in rabbit proximal tubule cells. The specificity of the receptor protein in these cells was confirmed using a specific Ang II receptor subtype siRNA. Because transfection of an $\mathrm{AT}_{1}$ receptor-specific siRNA effectively knocked down over $70 \%$ of $\mathrm{AT}_{1}$ receptor protein expression (Fig. 1), our results suggest that rabbit proximal tubule cells express predominantly $\mathrm{AT}_{1}$ receptors, equivalent to human $\mathrm{AT}_{1}$ receptors. Expression of endogenous $\mathrm{AT}_{1}$ receptors is essential for studying the effects of $\mathrm{AT}_{1}$ receptor-mediated endocytosis of extracellular Ang II on activation of NF- $\kappa \mathrm{B}$ in these cells. In a previous study in Ang II-infused rats, we showed that extracellular Ang II is accumulated in the intracellular endosomal compartments via $\mathrm{AT}_{1}$ receptor-mediated endocytosis. ${ }^{6}$ However, we do not know whether blockade of $\mathrm{AT}_{1}$ receptor-mediated endocytosis of extracellular Ang II has any biological relevance with respect to induction of NF- $\kappa \mathrm{B}$ activation.

Figure 2 shows the effects of Ang II on NF-KB activity and the potential role(s) of $\mathrm{AT}_{1}$ and $\mathrm{AT}_{2}$ receptors and the endocytotic machinery in Ang II-induced NF- $\mathrm{\kappa B}$ activation in proximal tubule cells. Stimulation by Ang II $(1 \mathrm{nM})$ resulted in fourfold increases in NF- $\kappa B$ activity. The Ang II-induced increase in NF- $\kappa \mathrm{B}$ activity was significantly attenuated by coadministration of losartan $(10 \mu \mathrm{M})$, an $\mathrm{AT}_{1}$ receptor-selective blocker, or colchicines (1 $\mu \mathrm{M})$, a selective cytoskeleton microtubule inhibitor. ${ }^{17,19}$ Because losartan blocks not only cell surface $\mathrm{AT}_{1}$ receptor-mediating signaling, but also $9,14,17$ we believe the effect of losartan on $\mathrm{AT}_{1}$ receptor-mediated endocytosis, Ang II-increased NF- $\mathrm{\kappa B}$ activity was mediated at least in part by inhibiting Ang II endocytosis. Although $\mathrm{AT}_{2}$ receptors have been shown to mediate NF- $\kappa B$ activation in vascular smooth muscle cells, endothelial cells or COS-7 cells expressing mutant $\mathrm{AT}_{2}$ receptors, ${ }^{10,22}$ we found that blocking $\mathrm{AT}_{2}$ receptors with PD123319 $(10 \mu \mathrm{M})$ had no significant effect on Ang II-induced NF- $\mathrm{kB}$ activity. The reasons underlying the differences between proximal tubule cells expressing endogenous receptors and those transfected with mutant receptors are not known, because at $10 \mu \mathrm{M}$ this compound almost completely blocks $\mathrm{AT}_{2}$ receptor binding in both nonrenal and renal cells expressing $\mathrm{AT}_{2}$ receptors. ${ }^{9}$ Furthermore, $\mathrm{AT}_{2}$ receptors have been reported to oppose, rather than induce $\mathrm{AT}_{1}$ receptor-mediated responses. ${ }^{9}$

The effect of colchicine on Ang II-induced NF- $\mathrm{kB}$ activation further suggests that $\mathrm{AT}_{1}$ receptor-mediated endocytosis may play a role in inducing NF- $\kappa B$ activation by Ang II. While colchicine does not have a direct effect on $\mathrm{AT}_{1}$ receptor binding, it selectively inhibits 
endocytosis and intracellular trafficking of various proteins by disrupting cell cytoskeleton microtubules. ${ }^{17,19}$ Colchicine also inhibits protein kinase $\mathrm{C}$ and phospholipase $\mathrm{C}$ activation by Ang II after endocytosis 26 and blocks intracellular Ang II accumulation in proximal tubule cells. ${ }^{17}$ Our results therefore suggest that cytoskeleton microtubules play an important role in $\mathrm{AT}_{1}$ receptor-mediated endocytosis of extracellular Ang II and subsequent activation of NF$\kappa \mathrm{B}$.

Activation of NF- $\kappa \mathrm{B}$ and its subsequent translocation to the cell nucleus play an important role in promoting transcription of growth factors and proliferative cytokines, which stimulates cell growth and proliferation. ${ }^{12,13}$ In the present study, we first determined whether Ang IIinduced activation of NF- $\mathrm{KB}$ is associated with stimulation of proximal tubule cell proliferation and then studied whether $\mathrm{AT}_{1}$ receptor-mediated endocytosis is involved. FIGURE 3 shows that Ang II increased ${ }^{3} \mathrm{H}$-thymidine incorporation by 55\%, and the effect of Ang II was significantly attenuated by coadministration of the $\mathrm{AT}_{1}$ receptor blocker losartan and the cytoskeleton microtubule inhibitor colchicine. Again, these results highlight the importance of the Ang II endocytosis/NF- $\mathrm{B}$ activation signaling cascade in promoting proximal tubule cell proliferation. Our results are consistent with previous studies in Ang II-infused rats or rats with overexpression of human renin and angiotensinogen showing that Ang II increased NF- $\mathrm{B}$ activity and induced tubulo-interstitial inflammation and fibrosis in the kidney. ${ }^{3,10}$ Blockade of NF- $\kappa \mathrm{B}$ activation and translocation to the cell nucleus may therefore provide therapeutic benefits in preventing and treating experimental and/or clinical Ang II-dependent hypertensive renal injury.

\section{Acknowledgements}

This work was supported by a National Institute of Diabetes, Digestive, and Kidney Diseases Grant (RO1DK067299, to J.L.Z.), an American Heart Association Grant-in-Aid (0355551Z, to J.L.Z.), and a National Kidney Foundation of Michigan Grant-in-Aid (to J.L.Z.). Dr. Carretero is supported by a National Heart, Lung, and Blood Institute Program Project Grant (HL-28982).

\section{References}

1. Johnson RJ, Alpers CE, Yoshimura A, et al. Renal injury from angiotensin II-mediated hypertension. Hypertension 1992;19:464-474. [PubMed: 1568765]

2. Suzuki Y, Ruiz-Ortega M, Egido J. Angiotensin II: a double-edged sword in inflammation. J Nephrol 2000;13(Suppl 3):S101-S110. [PubMed: 11132026]

3. Muller DN, Dechend R, Mervaala EM, et al. NF-אB inhibition ameliorates angiotensin II-induced inflammatory damage in rats. Hypertension 2000;35:193-201. [PubMed: 10642297]

4. Ruiz-Ortega M, Lorenzo O, Egido J. Angiotensin III increases MCP-1 and activates NF- $\mathrm{BB}$ and AP-1 in cultured mesangial cells and mononuclear cells. Kidney Int 2000;57:2285-2298. [PubMed: 10844599]

5. Zhuo JL, Imig JD, Hammond TG, et al. Ang II accumulation in rat renal endosomes during Ang IIinduced hypertension: role of AT(1) receptor. Hypertension 2002;39:116-121. [PubMed: 11799089]

6. Duff JL, Berk BC, Corson MA. Angiotensin II stimulates the p44 and p42 mitogen-activated protein kinases in cultured rat aortic smooth muscle cells. Biochem Biophys Res Commun 1992;188:257264. [PubMed: 1384482]

7. Kurtz TW, Gardner DG. Transcription-modulating drugs: a new frontier in the treatment of essential hypertension. Hypertension 1998;32:380-386. [PubMed: 9740599]

8. Schmitz U, Ishida T, Ishida M, et al. Angiotensin II stimulates p21-activated kinase in vascular smooth muscle cells: role in activation of JNK. Circ Res 1998;82:1272-1278. [PubMed: 9648723]

9. de Gasparo M, Catt KJ, Inagami T, et al. International Union of Pharmacology. XXIII. The angiotensin II receptors. Pharmacol Rev 2000;52:415-472. [PubMed: 10977869]

10. Ruiz-Ortega M, Lorenzo O, Ruperez M, et al. Systemic infusion of angiotensin II into normal rats activates nuclear factor-kappaB and AP-1 in the kidney: role of AT(1) and AT(2) receptors. Am J Pathol 2001;158:1743-1756. [PubMed: 11337372] 
11. Mezzano SA, Ruiz-Ortega M, Egido J. Angiotensin II and renal fibrosis. Hypertension 2001;38:635638. [PubMed: 11566946]

12. Hoffmann A, Levchenko A, Scott ML, Baltimore D. The IkappaB-NF-kappaB signaling module: temporal control and selective gene activation. Science 2002;298:1241-1245. [PubMed: 12424381]

13. Stancovski I, Baltimore D. NF-kappaB activation: the I kappaB kinase revealed? Cell 1997;91:299_ 302. [PubMed: 9363938]

14. Ferguson SS. Evolving concepts in G protein-coupled receptor endocytosis: the role in receptor desensitization and signaling. Pharmacol Rev 2001;53:1-24. [PubMed: 11171937]

15. Romero MF, Douglas JG, Eckert RL, et al. Development and characterization of rabbit proximal tubular epithelial cell lines. Kidney Int 1992;42:1130-1144. [PubMed: 1280703]

16. Zhuo JL, Li XC, Garvin JL, et al. Intracellular angiotensin II induces cytoplasmic $\mathrm{Ca}^{2+}$ mobilization by stimulating intracellular $\mathrm{AT}_{1}$ receptors in proximal tubule cells. Am J Physiol Renal Physiol 2006;290:F1382-F1390. [PubMed: 16380461]

17. Li XC, Carretero OA, Navar LG, Zhuo JL. AT $1 \mathrm{a}$ receptor-mediated accumulation of extracellular angiotensin II in proximal tubule cells: role of cytoskeleton microtubules and tyrosine phosphatase. Am J Physiol Renal Physiol 2006;291:F375-F383. [PubMed: 16478976]

18. Vazquez J, Adjounian MF, Sumners C, et al. Selective silencing of angiotensin receptor subtype 1a $\left(\mathrm{AT}_{1 \mathrm{a}} \mathrm{R}\right)$ by RNA interference. Hypertension 2005;45:1-5.

19. Elkjaer ML, Birn H, Agre P, et al. Effects of microtubule disruption on endocytosis, membrane recycling and polarized distribution of aquaporin-1 and gp330 in proximal tubule cells. Eur J Cell Biol 1995;67:57-72. [PubMed: 7543847]

20. Anderson KM, Peach MJ. Receptor binding and internalization of a unique biologically active angiotensin II-colloidal gold conjugate: morphological analysis of angiotensin II processing in isolated vascular strips. J Vasc Res 1994;31:10-17. [PubMed: 7903871]

21. Ruiz-Ortega M, Lorenzo O, Ruperez M, et al. Angiotensin II activates nuclear transcription factor kappaB through AT(1) and AT(2) in vascular smooth muscle cells: molecular mechanisms. Circ Res 2000;86:1266-1272. [PubMed: 10864918]

22. Wolf G, Wenzel U, Burns KD, et al. Angiotensin II activates nuclear transcription factor-kappaB through AT1 and AT2 receptors. Kidney Int 2002;61:1986-1995. [PubMed: 12028439]

23. Wolf G, Ziyadeh FN, Zahner G, Stahl RA. Angiotensin II-stimulated expression of transforming growth factor beta in renal proximal tubular cells: attenuation after stable transfection with the c-mas oncogene. Kidney Int 1995;48:1818-1827. [PubMed: 8587241]

24. Li XC, Carretero OA, Shao Y, Zhuo JL. Glucagon receptor-mediated extracellular signal-regulated kinase 1/2 phosphorylation in rat mesangial cells: role of protein kinase A and phospholipase C. Hypertension 2006;47:580-585. [PubMed: 16391176]

25. Ruiz-Ortega M, Egido J. Angiotensin II modulates cell growth-related events and synthesis of matrix proteins in renal interstitial fibroblasts. Kidney Int 1997;52:1497-1510. [PubMed: 9407495]

26. Schelling JR, Hanson AS, Marzec R, Linas SL. Cytoskeleton-dependent endocytosis is required for apical type 1 angiotensin II receptor-mediated phospholipase $\mathrm{C}$ activation in cultured rat proximal tubule cells. J Clin Invest 1992;90:2472-2480. [PubMed: 1334976] 

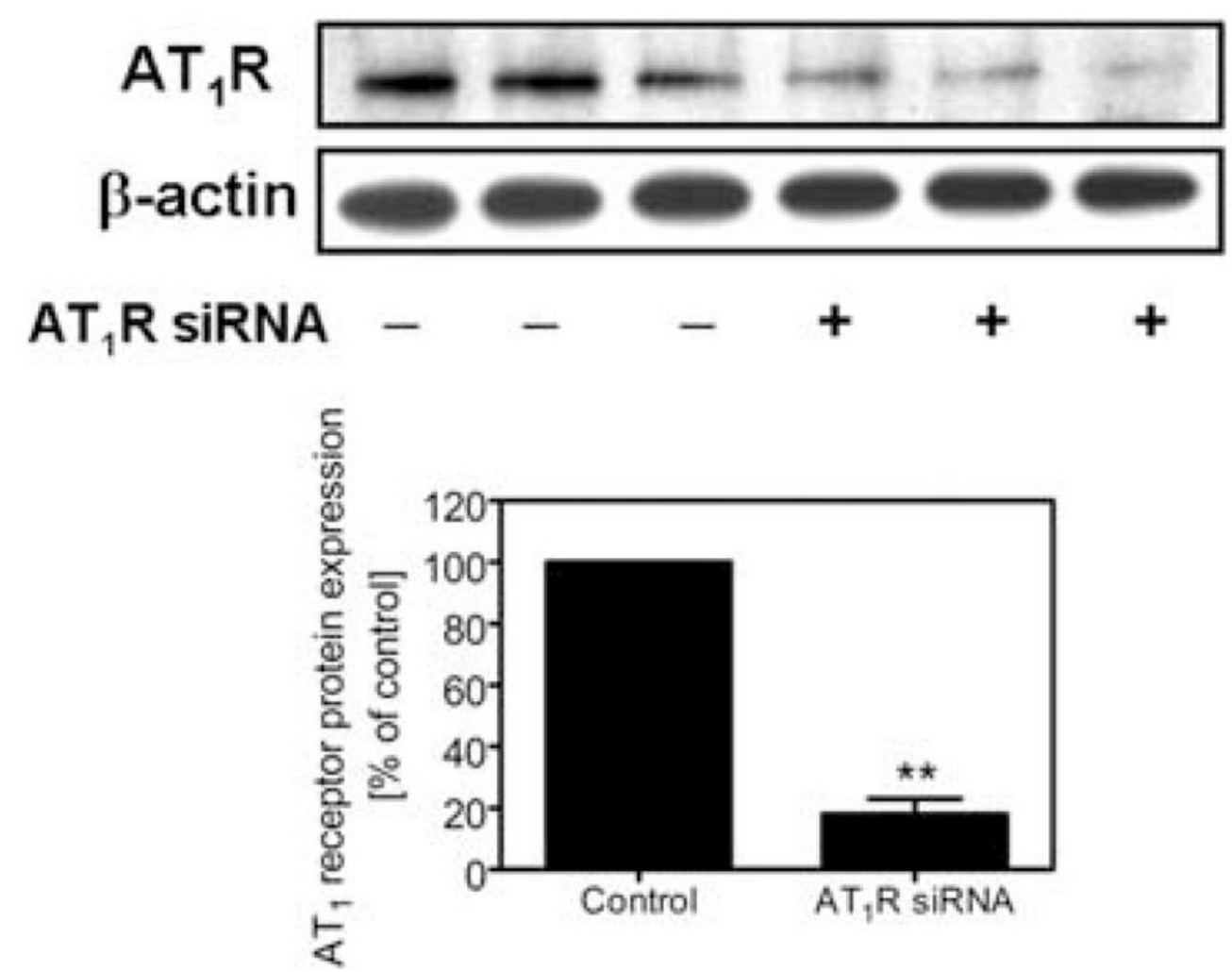

FIGURE 1.

Expression of specific $\mathrm{AT}_{1 \mathrm{a}}$ receptor protein in cultured rabbit proximal tubule cells. Top panel shows Western blots of $\mathrm{AT}_{1}$ receptor protein $(\sim 42 \mathrm{kDa})$ and $\beta$-actin, with the latter used to confirm equal loading. Bottom panel shows semi-quantitative data from control cells and cells transfected with an $\mathrm{AT}_{1}$ receptor siRNA, which specifically knocks down $\mathrm{AT}_{1}$ receptor protein expression. ** $P<0.01$ versus control. 
(A)

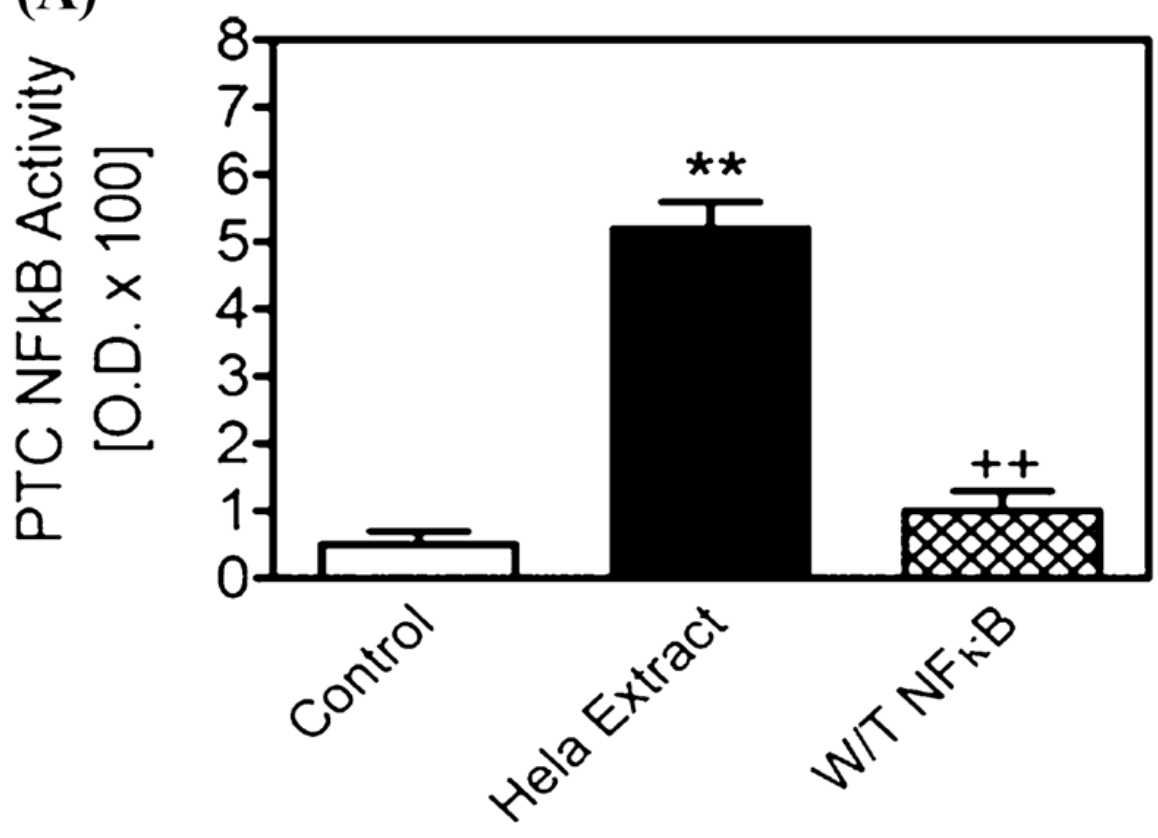

(B)
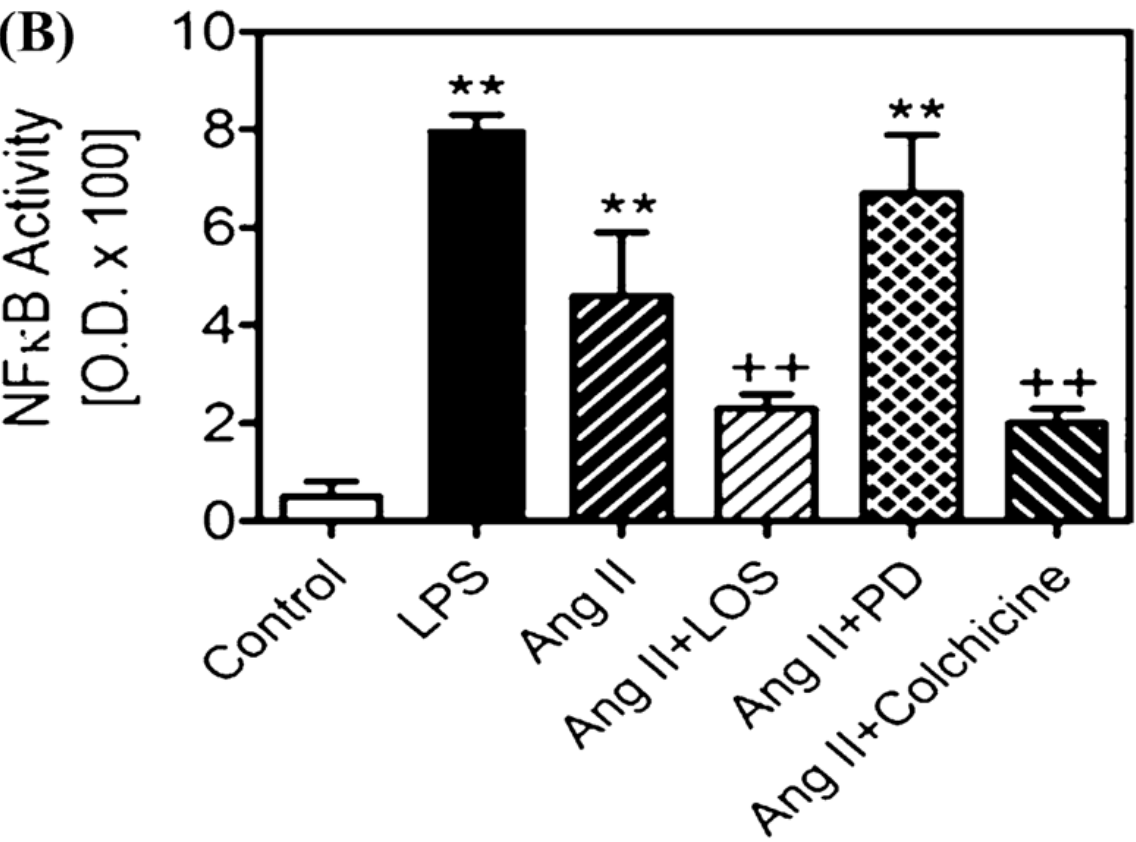

FIGURE 2.

Effects of Ang II and endocytotic inhibitors on Ang II-induced activation of nuclear factor$\kappa \mathrm{B}(\mathrm{NF}-\kappa \mathrm{B})$ in cultured rabbit proximal tubule cells. The top panel shows the specificity of Trans NFKB ELISA for measurement of activated p65 and p50 (Active Motif). HeLa extract and lipopolysaccharide (LPS) were used as a positive control and wild-type NF- $\mathrm{B}$ for a negative control. The bottom panel shows that both LPS and Ang II increased NF- $\kappa$ B activity, and the effect of Ang II was attenuated by losartan and colchicine, both of which block $\mathrm{AT}_{1}$ receptor-mediated Ang II endocytosis. $* * P<0.01$ versus control; $+P<0.01$ versus Ang II alone. 


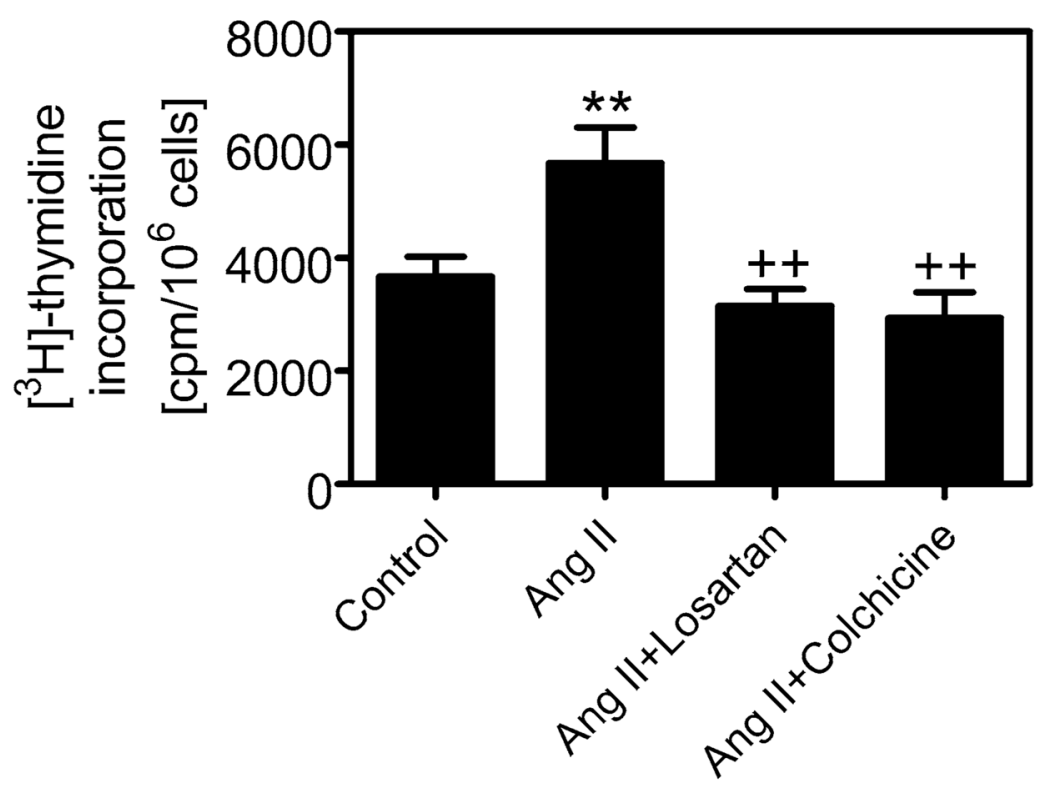

FIGURE 3.

Effect of Ang II and endocytotic inhibitors losartan and colchicine on Ang II-induced increases in $\left[{ }^{3} \mathrm{H}\right]$-thymidine incorporation in cultured rabbit proximal tubule cells. Note that Ang II increased $\left[{ }^{3} \mathrm{H}\right]$-thymidine incorporation, which serves as an index of DNA synthesis and cell proliferation, and that losartan and colchicine significantly attenuated Ang II-induced cell proliferation. $* * P<0.01$ versus control; $+P<0.01$ versus Ang II alone. 